Н. С. Медвідь

\title{
УРЯДОВО-КАНЦЕЛЯРСЬКА МОВА ГЕТЬМАНЩИНИ
}

Медвідь Н. С. Урядово-канцелярська мова Гетьманщини.

У статті визначено роль мови в державотворенні, охарактеризовано мовну політику та особливості функціонування урядово-канцелярської мови в Українській козацько-гетьманській державі.

Ключові слова: мовна політика, мовна інтеграція, українська урядовоканцелярська мова.

Медведь Н. С. Правительственно-канцелярский язык Гетманщины.

В статье определена роль языка в процессе создания государства, даны характеристики языковой политике и особенностям функционирования правительственно-канцелярского языка в Украинском казацко-гетманском государстве.

Ключевые слова: языковая политика, языковая интеграция, украинский правительственно-канцелярский язык.

() Н. С. Медвідь, 2013. 


\section{Medved N. S. The government-clerical language of Getmanschina.}

The article defines the role of language in the process of state creation, characterized by the language policy and features of functioning of the government-clerical language in Ukrainian Cossack Hetman state.

Key words: language policy, language integration, government-clerical Ukrainian language.

Пошук витоків сучасних проблем мовної політики та мовної ситуації в Україні й оптимальних шляхів їх вирішення спонукає до аналізу державотворчих процесів та історії становлення української мови. Цінною $є$ також інтерпретація мовних явищ, зумовлених політичними подіями в державі. На визначальній ролі мови в державотворенні неодноразово наголошували у своїх працях мовознавці, політологи, зокрема В. фон Гумбольдт, Х. Штейнталь, К. Фосслер, Ф. де Соссюр, Е. Сепір, Б. Уорф, В. Виноградов, О. Потебня, Л. Мацько, Л. Нікольський, О. Куць, I. Лопушинський, І. Плотницька та ін. Проте особливості функціонування урядово-канцелярської мови в Українській козацько-гетьманській державі залишаються мало вивченими.

Мета статті - охарактеризувати мовну політику та особливості функціонування урядово-канцелярської мови в Українській козацькогетьманській державі.

Закономірно, що піднесення та функціонування мови значною мірою зумовлюються суспільно-політичним розвитком суспільства й моделлю держави. Від цих чинників залежать не лише зміни в мові, але $\mathrm{i}$ ii існування, оскільки мова існує доти, доки існує певний етнос. Мова зникає в результаті втрати державної незалежності, асиміляції панівною нацією в багатомовній державі чи внаслідок фізичного винищення народу. Наприклад, на початку XVIII століття внаслідок «онімечення» зникли прусська і полабська мови.

Нерозривність життя мови та народу підкреслювали В. фон Гумбольдт, Х. Штейнталь, але науковці не враховували соціальних реалій. Мова, за визначенням В. фон Гумбольдта, є духом, тобто свідомістю народу [3]. У ній національна мовна особистість зі специфічною картиною світу зберігає та передає духовні багатства нації, соціальні, культурні, естетичні та інші цінності, прийняті в суспільстві на певному історичному етапі розвитку. Мова здійснює національну ідентифікацію людей і кваліфікацію етносів.

Питання співвідношення мови i держави набуває актуальності 3 XVIII століття, коли в Свропі почали утворюватися перші нації-держави та утвердився принцип «одна нація - одна мова - одна держава» [2, с. 101]. Процеси взаємодії мови та держави визначають мовну політику країни «сукупність ідеологічних постулатів і практичних дій, спрямованих на регулювання мовних відносин у державі або на розвиток мовної системи у певному напрямі» [1, с. 357]. Держава стає потужним чинником не лише 
соціальної, а й мовної інтеграції, тому провідною $є$ тенденція утворення єдиної мови на території єдиної держави. Без мови неможливе адекватне функціонування держави, оскільки всі види діяльності людини пов'язані 3 іiі комунікацією, опосередковані нею.

На межі XIX i XX ст. починає досліджуватися суспільна природа мови ученими французької соціологічної школи (А. Мейє, Ж. Вандрієс, $Ф$. де Соссюр та ін.) та Петербурзької лінгвістичної школи (І. Бодуен де Куртене). Науковці розглядають мову як відображення суспільної свідомості, як знаряддя, яке соціалізує і консолідує людство.

В. Нерознак відзначає особливу роль державної мови як мови, що виконує інтеграційну функцію в межах конкретної країни в політичній, офіційній, культурній сферах [6, с. 10]. Завдяки цій функції мова стає об'єднуючою духовною енергією народу, засобом для творчого перетворення матеріального світу у світ духовний.

Державна мова має особливу сферу функціонування. Вона $є$ мовою нормативно-правових актів держави, судочинства, державних органів влади та органів місцевого самоврядування. Державна мова забезпечує адекватність комунікацій органів державної влади між усіма суб'єктами державного управління. Вона $€$ комунікативним каналом між усіма громадянами держави, необхідним елементом для функціонування державного управління та розуміння державної волі, національною ознакою в міжнародних правовідносинах.

Для утвердження державності мови й розширення сфери iii функціонування, на думку Л. Мацько, потрібно задіяти комплекс чинників, серед яких провідним й організуючим $є$ процес формування й становлення україномовного державного апарату, усіх його гілок (законодавчої, правової, дипломатичної, адміністративно-управлінської) [5, с. 14].

Українська урядово-канцелярська мова за часів Гетьманщини функціонувала не тільки у внутрішньому, а й у зовнішньому офіційному спілкуванні з московською владою (листи Б. Хмельницького).

Урядово-канцелярські документи фіксують живе мовлення численних представників різних територіальних говірок та різних соціальних верств і груп (селян, козаків, міщан, старшини), дають матеріал для хронологічно послідовного дослідження системи народно-розмовної мови, іiї розвитку та еволюції офіційно-ділового стилю. Мова і стиль актів засвідчують усталеність у діловодстві, що підтверджується використанням однотипних початків і кінцівок, фахових термінів і зворотів, дотримання зразків правових кодексів тощо.

Із посиленням централізації влади у Російській імперії, і відповідно обмеженням української автономії, мовна політика поступово змінюється у напрямі звуження функцій української мови. Наприкінці XVIII ст. вона була витіснена із судів і державних установ.

○ Н. С. Медвідь, 2013. 
Офіційні заборони в першу чергу стосувалися мови української церкви, яка з 1684 року перебувала під владою Московського патріархату. Це зумовило переведення видавничої та освітньої справи під московську цензуру, яка прагнула того, щоб «никакой розни й особого нарђчия не было» [1, с. 358].

У 1720 році видається указ про заборону видання Києво-Печерською i Чернігівською друкарнями нецерковних книг та про друк книг лише російським варіантом церковнослов'янської мови. Витіснення українського варіанта церковнослов'янської мови 3 церковного вжитку спричинило зміну мовної орієнтації шкіл та Київської академії, що, у свою чергу, прискорило зросійщення суспільного життя в Україні.

А. Кримський, оцінюючи стан української мови у XVI-XVIII ст., відзначав: «...Багате письменство XVI-XVIII вв. 3 періоду боротьби проти унії, коли спільні релігійні інтереси сполучували православних малорусів і православних білорусів в одне тіло, так само не користувалося чистою малорущиною; граматика Мелетія Смотрицького 1618 року попросту аж узаконювала панування церковно-слов'янської мови, принаймні теоретично. А вже ж ще до лексики, то письменство цеє вживало особливої мішанини, аж надто незграбного жаргону («язичія» за пізнішою термінологією), де неорганічно зливалися до купи елементи церковно-слов'янські, польські і малоруські (вони рівночасно і білоруські). Найдавніші пам'ятники, писані чистісінькою малоруською мовою, а не отаким язичієм, це записи народніх пісень XVI-XVIII віку, драматичні жартівливі інтермедії з початку XVII віку (Гаватович та інші), вірші XVII-XVIII віку. Густо-часто писано їх буквами латинськими, а не священною церковно-слов'янською кирилицею. 3 отакої простонародної літератури XVII-XVIII віку, підо впливом теж ідей західньоєвропейського романтизму XVIII віку, виріс на Наддніпрянській Україні отой язиково демократичний літературний рух, що його виразником зробилися Котляревський i інші талани. Рух цей у своєму народолюбстві перевів із повною послідовністю принціп: користуватися українською мовою в ії непідробленому, живому вигляді, отак, як нею балакають прості люди» [8, с. 114].

Мовою державних канцелярій була староукраїнська, яка, на думку I. Матвіяса, «в історії нашого народу відіграла надзвичайно важливу роль. Вона використовувалась для потреб релігії, освіти, науки, нею писалися ділові документи, церковно-публіцистичні полемічні твори, художня література, вона обслуговувала державно-адміністративні і дипломатичні потреби козацько-гетьманської України... Староукраїнська літературна мова набула широкого застосування як у рукописному, так і в друкованому (з другої половини XVI ст.) виявах, як у писемній, так і в усній формі» [4, с. 161].

Видатна роль у шліфуванні ділового стилю української літературної мови XVII-XVIII ст. і виробленні iї узусу, своєрідного койне, що поширювалися через універсали та листи гетьманів на більшій частині української етнічної території, належить гетьманським державним органам. 
Ділова документація Гетьманщини зосереджувалася в канцеляріях. Питаннями стосунків царського уряду з Лівобережною Україною на різних історичних етапах займалися канцелярії при Посольському приказі, при Малоросійській колегії, Канцелярія міністерського правління, Канцелярія малоросійського генерал-губернатора.

У Генеральній військовій канцелярії видавалися важливі укази та розпорядження щодо питань поточного державного управління. На час військових походів створювалася Похідна генеральна військова канцелярія, гетьманом К. Розумовським створена гетьманська канцелярія, прибутками i видатками 3 населення займалася Генеральна скарбова канцелярія, канцелярія діяла і при Генеральному військовому суді.

Виконавчим органом влади були полкові та сотенні канцелярії. Останні виконували військово-адміністративні і судові функції на території сотні як адміністративно-територіальної одиниці і підпорядковувалися полковим канцеляріям і полковим судам, а ті - Генеральній військовій канцелярії і Генеральному військовому судові.

У Генеральній військовій канцелярії Івана Мазепи (а потім і Пилипа Орлика) служили жителі тодішньої гетьманської столиці - м. Батурина, корінні мешканці і ті, хто приїхав з інших регіонів України. Живомовне середовище мало значний вплив на осіб з гетьманського оточення. За мапами українських діалектологів, Батурин розташований на теренах поширення лівобережнополіських говірок північного наріччя української мови. Іноді на цій території відзначають нашарування говорів південно-східного наріччя української мови.

Дослідження «Договорів і постанов прав і вольностей військових...» 1710 року переконує в тому, що в пам'ятці знайшов відображення узус української писемно-літературної мови початку XVIII ст., її лексичне і стильове багатство, зафіксоване койне правлячих кіл гетьманської України, що поєднувало риси південно-східного наріччя (воно функціонувало на більшій території Гетьманату) з елементами північного (на терені функціонування якого тоді розташована була його столиця - місто Батурин). В. Німчук відзначає, що «пам'ятка однозначно засвідчує дуже високий рівень розвитку юридичного стилю староукраїнської літературної мови початку XVIII ст., яка, грунтуючись на живому мовленні народу, ввібрала в себе численні елементи з тодішньої міжнародної мови європейців - латинської (прямо або через польську), а також була позначена помітним впливом польської, церковнослов'янської мов і незначним - російської» [7, с. 161].

Отже, українська урядово-канцелярська мова функціонувала не тільки у внутрішньому, а й у зовнішньому офіційному спілкуванні. Вона охоплювала сфери суспільно-політичного, суспільно-економічного життя народу, правових відносин, державного управління, суду, ділових стосунків тощо. Перспективи подальших розвідок вбачаємо у вивченні української мови канцелярій Гетьманщини XVII - XVIII ст.

○ Н. С. Медвідь, 2013. 


\section{Література}

1. Брицин В. М. Мовна політика / В. М. Брицин // Українська мова : енциклопедія / редкол. : В. М. Русанівський, О. О. Тараненко (співголови), М. П. Зяблюк [та ін.]. - [3-є вид., зі змінами і доп.]. - К. : Українська енциклопедія ім. М. П. Бажана, 2007. - С. 357-361.

2. Герасимова O. Держава i мова в контексті процесів глобалізації / О. Герасимова // Політичний менеджмент. - 2007. - № 5. - С. 99-104.

3. Гумбольдт В. фон. Избранные труды по языкознанию / Вильгельм фон Гумбольдт ; [пер. с нем.]. - М. : Прогресс, 2000. - 398 с.

4. Матвіяс І. Варіанти української літературної мови : [монографія] / Іван Матвіяс. К. : НАУ ІУМ, 1998. $-162 \mathrm{c}$.

5. Мацько Л. І. Державна мова України / Л. І. Мацько // Проблеми розвитку і застосування мов в Україні. - Вип. ІІ. - К. : Просвіта, 1998. - С. 14-20.

6. Нерознак В. П. Государственные языки в Российской Федерации / В. П. Нерознак. - М. : Академия, 1995. - 246 с.

7. Німчук В. «Договори і постанови прав і вольностей військових...» 1710 року 3 погляду історії української мови» / В. Німчук // «Пакти і Конституції» Української козацької держави (до 300-річчя укладення) / відп. ред. В. А. Смолій ; упорядники : М. С. Трофимук, Т. В. Чухліб. - Львів : Світ, 2011. - С. 27-60.

8. Шахматов О. Нариси 3 історії української мови та хрестоматія з пам'ятників письменської старо-українщини XI-XVIII вв. / О. Шахматов, А. Кримський. - К. : Друкар, 1922. - 188 с. 